\title{
GB-InSAR monitoring and observational method for landslide emergency management: the Montaguto earthflow (AV, Italy)
}

\author{
Federica Ferrigno, Giovanni Gigli, Riccardo Fanti, Emanuele Intrieri, and Nicola Casagli \\ Department of Earth Sciences, University of Florence, Via La Pira 4, Florence, Italy \\ Correspondence to: Federica Ferrigno (federica.ferrigno@unifi.it)
}

Received: 23 October 2015 - Discussion started: 7 December 2015

Revised: 14 April 2017 - Accepted: 4 May 2017 - Published: 9 June 2017

\begin{abstract}
On 10 March 2010, because of the heavy rainfall in the preceding days, the Montaguto landslide (Southern Italy) reactivated, affecting both state road 90 "Delle Puglie" and the Rome-Bari railway. A similar event occurred on May 2005 and on September 2009. As a result, the National Civil Protection Department (DPC) started an accurate monitoring and analysis program. A monitoring project using the GB-InSAR (ground-based interferometric synthetic aperture radar) system was emplaced to investigate the landslide kinematics, plan urgent safety measures for risk mitigation and design long-term stabilization work.

Here, we present the GB-InSAR monitoring system results and its applications in the observational method (OM) approach. GB-InSAR is an established instrument for longterm campaigns aimed at early warning and monitoring during construction works. Our paper further develops these aspects in that it highlights how the OM based on the GBInSAR technique can produce savings in terms of cost and time in engineering projects without compromising safety. This study focuses on the key role played by the monitoring activities during the design and planning activities, with special reference to the emergency phase.
\end{abstract}

\section{Introduction}

Landslides represent a major geohazard, often causing damage to infrastructure and significant economic loss. To mitigate risks associated with the landslide and to support its management, recent studies have employed new monitoring technologies (Barla et al., 2010; Azteni et al., 2001; Balducci et al., 2011; Badoux et al., 2009; Allasia et al., 2013).
Unfortunately, the preventive measures for risk mitigation are often lacking or not adequate to guarantee the safety of the people and infrastructure involved in complex landslide systems.

However, new tools such as ground-based interferometric synthetic aperture radar (GB-InSAR) can be used to monitor landslide motion and reduce landslide risk by providing early warnings (Intrieri et al., 2012; Carlà et al., 2016). Thus, monitoring with advanced technology and its use in landslide management can be an efficient method for landslide risk management.

The major damage related to the Montaguto earthflow was communication route interruption.

Based only on the Italian Railway System evaluations (www.fsnews.it), the landslide caused an estimated loss of 620.00 EUR week $^{-1}$. To guarantee the restoration of the infrastructure, it was necessary to quickly and simultaneously accomplish the following activities:

- remove the landslide accumulation from the communication routes,

- stabilize the landslide and

- guarantee the operating workers' safety.

To achieve these tasks, a multidisciplinary emergency team was established and coordinated by the National Civil Protection Department (DPC). Based on a cost-benefit analysis, the implementation of a monitoring network capable to monitor and address the design work was conducted; this was composed of and a near-real-time monitoring GBInSAR system. The DPC also availed of a robotic total station (RTS) network in order to have two independent systems and to guarantee, in case of any interruption or system breakdown, the landslide monitoring coverage. The RTS 
campaign has been described by Giordan et al. (2013) and Lollino et al. (2014). Moreover, 3-D displacements products for the Montaguto landslide were obtained using other monitoring techniques, such as multitemporal airborne lidar data (Ventura et al., 2011).

The nature of the data obtained from these different techniques is complementary and thus they are not directly comparable. In particular, due to the Montaguto landslide features, the GB-InSAR system is more suitable for detecting the unstable sectors providing areal displacement data that are essential to design or modify the work plan, whereas the RTS system is able to acquire punctual displacement data that are very useful to monitor single points and/or the stability of the structures realized on the landslide; in this study, only data from GB-InSAR monitoring are presented and analyzed, while the RTS campaign has been described in Giordan et al. (2013) and in Lollino et al. (2014).

In particular, the immediate availability of multitemporal deformation maps in near-real time during response and recovery phase of the emergency management cycle for the landslide rapid mapping of displacements was a key point to support civil protection and a standard practice in operational service (Boccardo, 2013). In this framework, the GB-InSAR technique and the growing capability of current techniques to monitor a wide range of deformation processes play a fundamental role.

The use of GB-InSAR as a landslide monitoring technique has been well documented in the last decade, with applications in different risk scenarios (Tarchi et al., 2003a, b; Canuti et al., 2003; Casagli et al., 2010) as well as in other earthflows (Lombardi et al., 2016; Bardi et al., 2017). In some cases, the system was used for controlling slope movements that threatened one or more lifelines (Casagli et al., 2008; Gigli et al., 2011, 2014; Bozzano et al., 2011; Intrieri et al., 2015), as in the Montaguto site.

The GB-InSAR technique is particularly suitable for monitoring landslides that are characterized by rapid evolution because of the following characteristics:

1. high SAR image sampling frequency (every few minutes);

2. operation under any weather and lighting condition;

3. complete remote operability (no requirement for the installation of target sensors on the monitored slope);

4. accuracy and precision in the displacement measurement, ranging from sub-millimeter to a few millimeters;

5. continuous areal monitoring of the entire slope with high pixel resolution (from half to a few meters, depending on the distance);

6. long-range operability (up to $4 \mathrm{~km}$ ).
The main aim of this paper is to highlight the efficiency and the important role of a continuous, panoramic and highresolution monitoring system as a means of support in work design within the framework of the observational method $(\mathrm{OM})$, which is an approach integrating monitoring within construction works design. The application of the OM to the stabilization project in the Montaguto earthflow making use of GB-InSAR monitoring was characterized by three main phases:

- the emergency phase (when the main aim was the removal of the landslide accumulation from the state road 90 and the railway, lasting about 4 months, from March to July 2010): providing support to the work management;

- the long-term stabilization phase (lasting 3 years): data that inform and drive the project design;

- the post-operation phase (ongoing): involving monitoring of the landslide residual deformation.

\section{The Montaguto earthflow}

The Montaguto landslide is located in the Daunian Apennine (Campania region) in Southern Italy; it is one of the largest active earthflows in Europe (Fig. 1). The Campania region territory is widely subjected to hydrologically controlled instability processes, including several types of phenomena, such as subsidence, earthflows, mudflows, debris avalanches and flooding (Calò et al., 2012; Guadagno et al., 2005; Revellino et al., 2010). The primary predisposing factor to landslide in the area is the complex geological setting (Matano, 2002), with high tectonic and structural control on the drainage architecture via the effect of a network of faults and folds on the sedimentary units (Pescatore et al., 1996).

The Montaguto earthflow develops along the southern side of a relief and has carved its own valley and created a distinct morphology on the north-side slope of the Cervaro Valley. The landslide body spans a nearly $3 \mathrm{~km}$ and reaches the valley bottom (410 $\mathrm{m}$ a.s.l.), with an elevation drop of approximately $420 \mathrm{~m}$ (Fig. 1). The total flow volume is approximately $0.004-0.006 \mathrm{~km}^{3}$ (Giordan et al., 2013; Guerriero et al., 2013; Lollino et al., 2014); the landslide covers an area of $0.66 \mathrm{~km}^{2}$ and the average travel angle (or shadow angle, defined as the slope of a line joining the tip of the debris to the landslide crest of the main scarp) is $8.4^{\circ}$.

Based on the kinematic, morphological and lithological characteristics, the Montaguto landslide can be classified as an earthflow with slow, intermittent flow-like movement of plastic, clayey soil, facilitated by a combination of sliding along multiple discrete shear surfaces, internal shear strains and long periods of relative dormancy interrupted by more rapid "surges" (Hungr et al., 2013).

Based on the morphological characteristics, the landslide can be divided into three main zones (Fig. 1): (i) the upper 


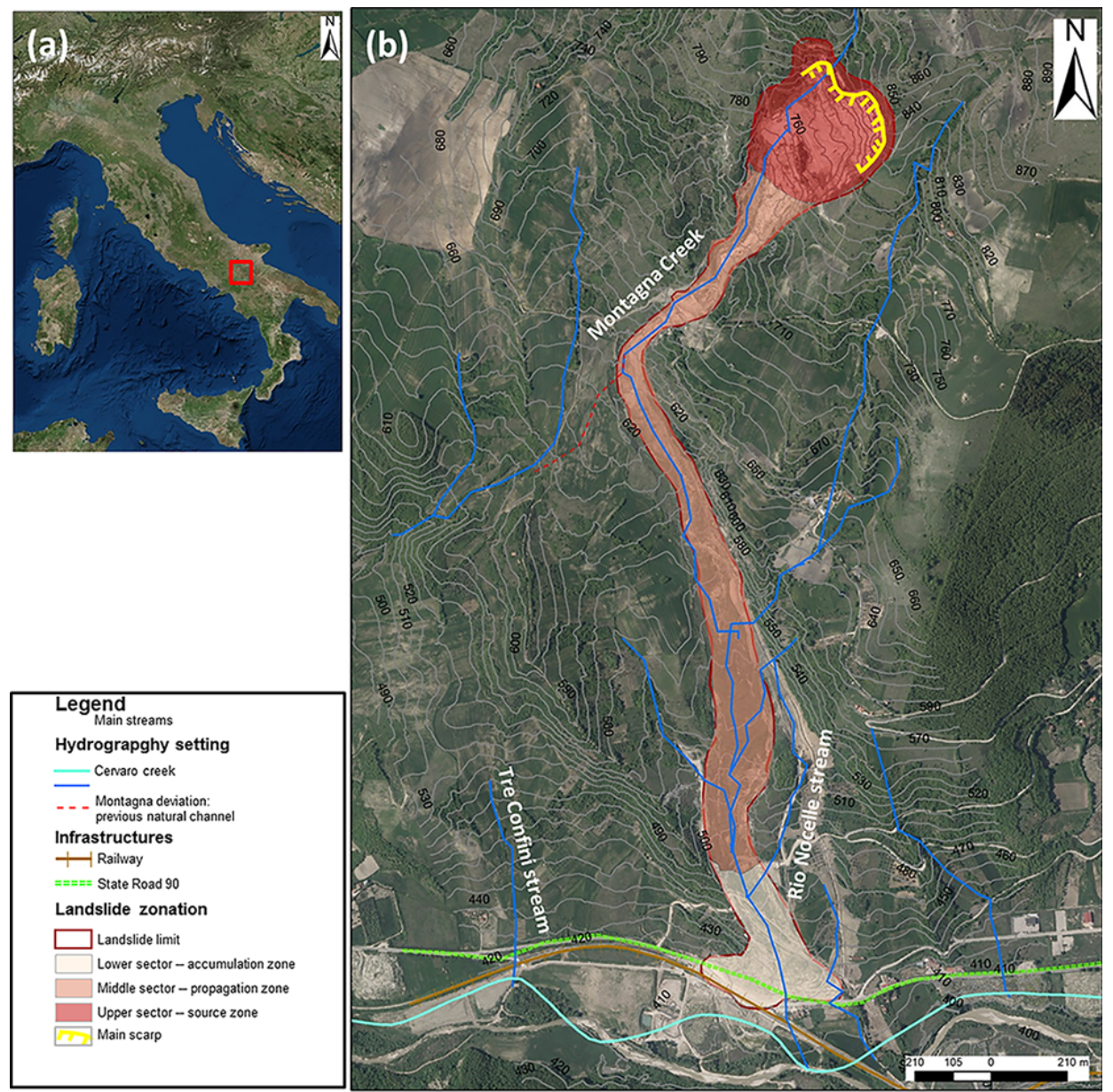

Figure 1. (a) Location map. (b) Map of the Montaguto area shown with the main landslide features, including the element at risk (infrastructures).

sector at approximately $750 \mathrm{~m}$ a.s.l., with the main scarp representing where the source area is located; (ii) the middle sector between 750 and $500 \mathrm{~m}$ a.s.l. that constitutes the propagation area; and (iii) the lower sector (landslide toe) below $500 \mathrm{~m}$ a.s.l, representing the accumulation zone. The upper sector of the slope presents a general WSW exposure, with secondary ridges oriented in the general direction of SW$\mathrm{NE}$, constituting the source area and spanning about $100 \mathrm{~m}$ (Fig. 1); the lower middle of the slope is exposed to the south with the hydrographic network and secondary ridges oriented in the general direction of SSE-NNW.

The outcropping lithologic units in the study area (Fig. 2) include clay, sandy marl, limestone, clayey marl, marly calcareous conglomerate and clayey flysch; these units influence the morphology and the hydrography, causing significant articulation from strong structural controls (Crostella and Vezzani, 1964). Along the slope, starting from the upper area, densely stratified limestone, calcarenite, marl, clayey marl and clay belonging to the Faeto Flysch Formation (Langhian to Tortonian age) crop out (Crostella and Vezzani,
1964), whereas in the middle and lower areas clayey marl, fine sand and conglomerate (units 2, 3 and 4 in Fig. 2) pertaining to the Villamaina Unit (Messinian age) are observed (D'Argenio et al., 1975).

The landslide material is supposed to be mainly formed of restructured and remolded soils originally belonging to the Faeto Flysch Formation (Lollino et al., 2014), whereas the Villamaina Unit presumably represents the substratum over which the landslide mass has moved (Guadagno et al., 2005; Guerriero et al., 2013).

The earthflow source area presents a series of rotational scarps where weathered weak rock outcrops, whereas the body of the earthflow evolves in a lobate flow-like morphology that extends to the valley floor. A creek and a spring system runs through the body of the earthflow along its entire length. The landslide area located between the source area and the propagation area is supposed to be the transition area, where the landslide style changes from pure sliding to a proper earthflow (Lollino et al., 2014). 


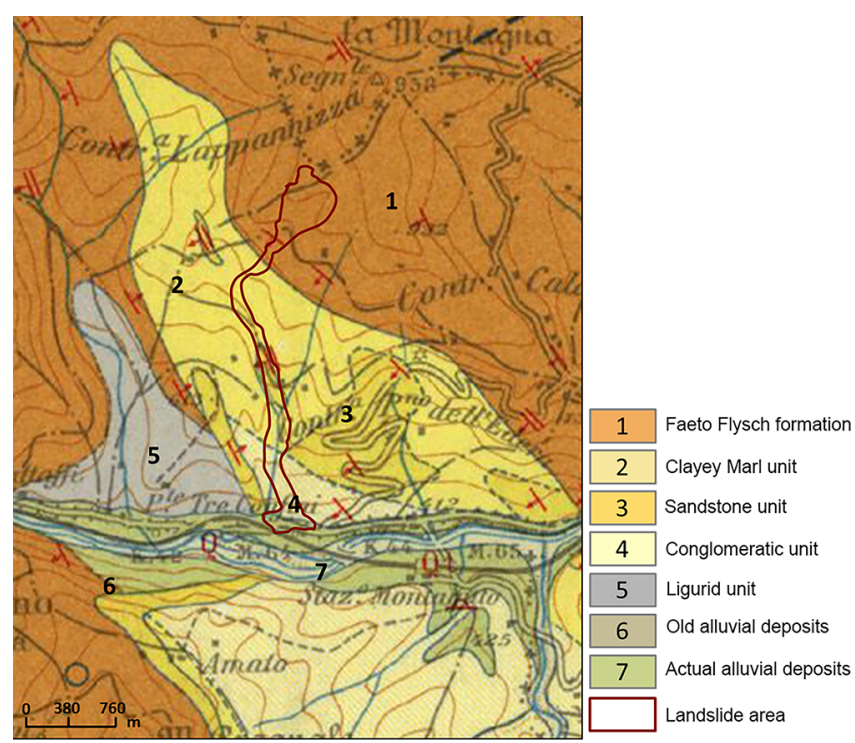

Figure 2. Geological setting: location of the landslide area (red line) and geological map of the study area (1: 100 000, Italian Geological Map No. 174 - Ariano Irpino), according to D' Argenio et al. (1975); the 2, 3, and 4 units have been described as the Villamaina Unit.

In such an earthflow case study, generally when the source slide becomes unstable, usually caused by a temporary increase in pore pressure with the consequentially decrease of resisting forces, the earthflow undergoes a surge (acceleration) (Hungr et al., 2013). The kinematics of the flowlike movement is subjected to several changes over time; the Montaguto earthflow is in fact characterized by long periods of quiescent behavior interrupted by more rapid events. These mechanisms were observed in similar earthflow phenomena, such as the Slumgullion earthflow in Colorado (USA) (Coe et al., 2003; Parise et al., 2003).

The first historical information (Fig. 3) related to instability phenomena along the road up to Montaguto dates back to 1763 , when the first stabilization works started. There are reports regarding the royal road and the Cervaro River being influenced by the occurrence of a lobate landslide deposit ("Il Mattino, ediz. Avellino del 20/7/2009; Vincenzo Grasso - Montaguto e la lezione dei Borboni"). Other documented reactivations occurred during the 2-year period from 1957 to 1958 (Guerriero et al., 2013). In the period of 1958-1980, the activity was very low. In 1990, a landslide external to the system interrupted the hydraulic connection between the Montagna Creek and the Tre Confini River, causing a change in the flow path in the Fosso Nocelle.

In 2003 and 2004, minor landslide reactivations occurred, with the active part (between elevation 830 and $460 \mathrm{~m}$ a.s.l.) of the landslide covering the deposits of the inactive landslide. Other periods of mobilization occurred between January and May 2006, when the landslide continued to advance towards the valley bottom and crossed the highway
(Lollino et al., 2014). The infrastructure was involved again in September 2009.

On 10 March 2010, a major surge event occurred. Although no causalities occurred, serious damage to the highway and railroad infrastructure were recorded, with complete interruption of the two main transportation connections between the Campania and Puglia regions (Guerriero et al., 2013).

\section{Methods}

\subsection{The observational method}

The development and the use of the OM started in the 1940s. The historical evolution of the use of the OM started with Peck (1969) and Terzaghi et al. (1996). The OM had the aim to reduce the costs during construction that were caused by designing earth structures based on the most-unfavorable assumptions. Instead, the design according to the $\mathrm{OM}$ is based on the most-probable conditions rather than the mostunfavorable. Gaps in the available information are filled by observations: in this case by the monitoring data. These observations aid in assessing the landslide evolution, checking its velocity trend with respect to the ongoing works, and the behavior of the structure during construction, which can then be modified in accordance with the findings.

Usually, monitoring has the aim of verifying the functionality of the works over time, observing the relation between the design plan and the phenomena evolution. When coupled with the OM, the goal of monitoring, which plays an active role in both design and construction, is also to validate the adopted design solution or to identify the most appropriate design solution among the planned ones. The OM facilitates design changes during stabilization works and establishes a framework for risk management.

Peck discussed the OM in his 1969 Rankine lecture (Peck, 1969) and defined two OM approaches:

a. ab initio approach, adopted from inception of the project;

b. "best way out" approach, adopted after the project has commenced and some unexpected event has occurred that is different to the predefined design or failure occurs and where $\mathrm{OM}$ is required to establish a method of addressing a difficulty.

In this study, the adopted approach consists of three stages (Fig. 4): (i) understanding of the landslides features leading to the initial stabilization works design; (ii) variations and/or interruption of the works based on the monitoring activity output; and (iii) a design review stage to bring back the project to an operative condition.

GB-InSAR displacement measurements were checked with a frequency proportional to the velocity of the landslide. 


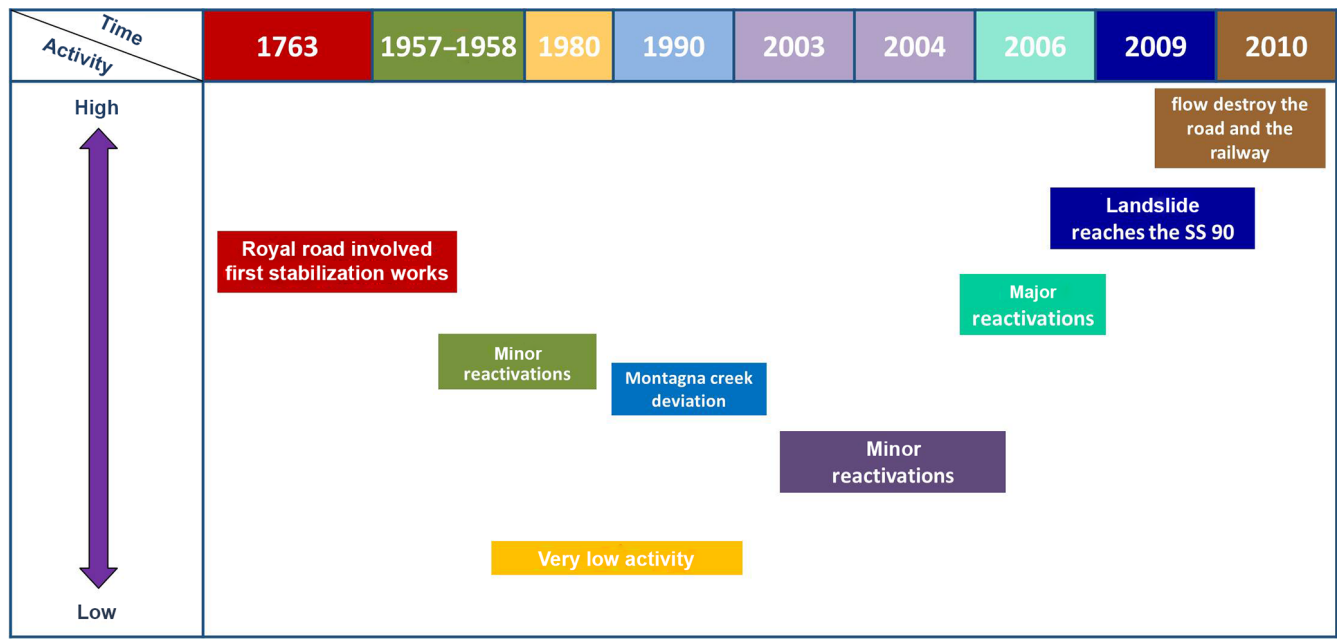

Figure 3. Timeline of the main landslide events recorded over the years.

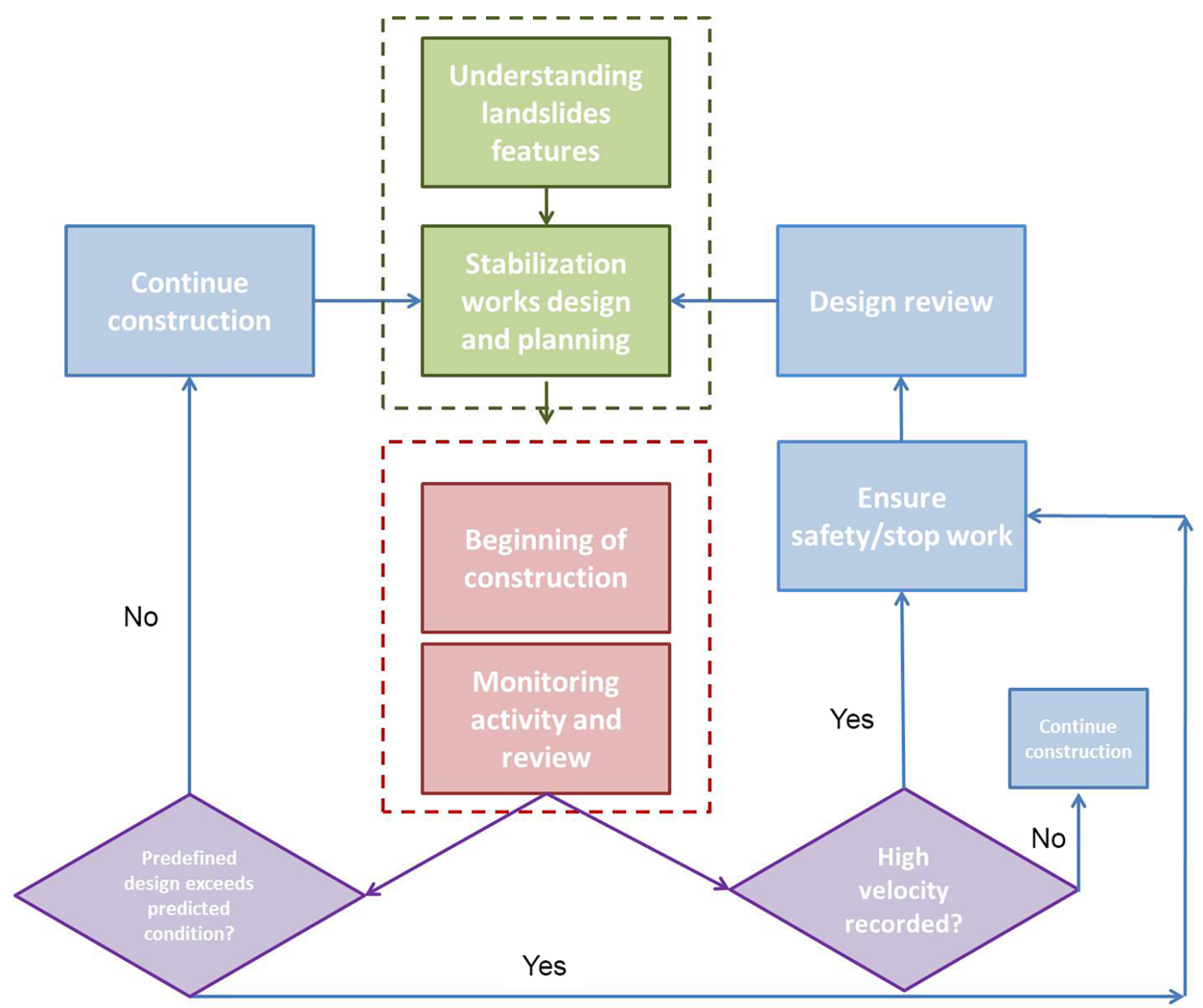

Figure 4. Conceptual flowchart of the application of the OM to the Montaguto remediation works.

During the emergency phase, specialized personnel was permanently at the monitoring center to provide continuous data check and validation. In the later months, during the most stable periods, data were still checked at least daily. Empirical velocity thresholds were implemented to define different warning levels. The results of the monitoring were dispatched to the stakeholders in the form of daily monitoring bulletins. Extraordinary bulletins were issued in case of sudden accelerations. Bulletins were used as support for decision making, within the framework of the OM.

When monitoring data review showed that the predefined design exceeds predicted condition or a velocity threshold is exceeded, this would then trigger a "recovery stage". This consists in implementing emergency planned measures to se- 
cure the safety of the site staff and the general public while the unexpected event is fully investigated. Any decision in this stage need to be made rapidly; for this reason the assessment will be qualitative rather than quantitative. Once the safety of the site has been secured, the project team has to bring the project back to a fully stable condition, which means first carrying out a "design review stage" comparing the actual conditions with the original design.

\subsection{The GB-InSAR monitoring system}

The GB-InSAR technique employs a radar system, which is composed of a coherent microwave trans-receiver unit based on SAR (Curlander and McDonough, 1991) and on interferometric techniques (InSAR), originally developed for earth observation from satellites (Zebker and Goldstein, 1986). The synthetic aperture is formed by moving the radar head along a linear rail.

The GB-InSAR system radiates microwaves on the investigated area to measure the backscattered signal, obtaining an SAR image and providing measurement of ground displacement through remote sensing. The system detects a continuous 2-D areal distribution of the occurred deformation within the observed ground portion, without the necessity of positioning targets on the ground and without any physical contact with the slope (Tarchi et al., 1997). The obtained SAR image is created based on the spatial resolution along the direction perpendicular (range resolution, $\Delta \mathrm{Rr}$ ) and parallel to the rail synthetic aperture (azimuth, or cross-range resolution; $\Delta$ Raz) (Luzi, 2010); each pixel in the image contains amplitude and phase information of the investigated scenario's backscattered echo.

By comparing the phase information between two radar acquisitions of the same scenario, it is possible to obtain a 2D displacement map of the investigated area that constitutes an interferogram (Luzi et al., 2004; Monserrat et al., 2014). One of the limitations of this technique is that only the displacement component parallel to the line of sight (LOS) can be measured; thus, displacements that occur along a direction perpendicular to the sensor are missed, making determination of the location of the installation point crucial (Fig. 5a).

Regarding the investigated site, the radar system was installed to ensure the sensor LOS is as parallel as possible to the expected direction of the landslide motion. The high precision (sub-millimeter) of the technique contributes to minimize this limit, detecting even small displacements. Other important limitations of the GB-InSAR technique are due to temporal decorrelation and atmospheric noises (Luzi et al., 2010).

On 29 April 2010, the apparatus was installed on the opposite slope located at approximately $4 \mathrm{~km}$ from the earthflow.

To optimize the monitoring system efficiency, the radar should be placed at a stable location, with the minimum presence of obstacles between the radar sensor and the investigated objects. The technical features of the GB-InSAR cam-
Table 1. Operational parameters set up for the GB-InSAR monitoring of the Montaguto landslide.

\begin{tabular}{lr}
\hline Rail length & $2.7 \mathrm{~m}$ \\
Minimum observed area distance & $800 \mathrm{~m}$ \\
Maximum observed area distance & $4000 \mathrm{~m}$ \\
Displacement estimate accuracy & $0.5-0.7 \mathrm{~mm}$ \\
Theoretical resolution in range (constant) & $\sim 3.5 \mathrm{~m}$ \\
Theoretical resolution in azimuth at $800 \mathrm{~m}$ & $\sim 3 \mathrm{~m}$ \\
Theoretical resolution in azimuth at $2000 \mathrm{~m}$ & $\sim 7 \mathrm{~m}$ \\
Theoretical resolution in azimuth at $4000 \mathrm{~m}$ & $\sim 14 \mathrm{~m}$ \\
Scan time interval & $3.5 \mathrm{~min}$ \\
\hline
\end{tabular}

paign at Montaguto are shown in Table 1 and in Fig. 5b. To detect both short- and long-term movements, interferograms with a temporal baseline spanning from $3.5 \mathrm{~min}$ to 1 month have been used.

During the GB-InSAR monitoring, data were transferred via ftp to the processing and post-processing unit for the generation and production of the interferograms (Fig. 6) and the monthly cumulated displacement maps (Fig. 7). Negative displacement values indicate a movement toward the sensor (shortening along the LOS), whereas positive displacement values indicate movement away from the sensor (lengthening along the LOS).

Based on the results of the landslide velocity pattern, the DPC, with the operational support of the Italian Army, started stabilization efforts using large earth-moving machinery along the toe of the earthflow. As a result of the monitoring and subsequent stabilization efforts, the railway was reopened on 7 June 2010 and the state road 90 was reopened on 10 July 2010.

The GB-InSAR system was one of the key elements in the work planning; worker safety was improved because alerts could be provided regarding sudden accelerations that required stoppage of work or evacuation.

During the first stages of the monitoring activity, for few weeks, the GB-InSAR instrument was partnered with a webcam and with an infrared thermal camera (IRT). A comparison between the optical images and the interferograms was crucial for the interpretation of the radar images and therefore the detection of unstable areas, especially of the landslide toe portion (Fig. 6), while the IRT allowed a very accurate investigation of the water flow paths, wet areas and drainage directions (Fig. 8). In an OM perspective, the individuation of wet and fast-moving areas (roughly coinciding) directed the design of the remediation works and allowed us to give priority to such particular areas and to all the interventions aimed at draining water from the landslide. This first emergency phase ended in July, when the displacement rate decreased as a result of the constructions and the dry season (Fig. 10). 


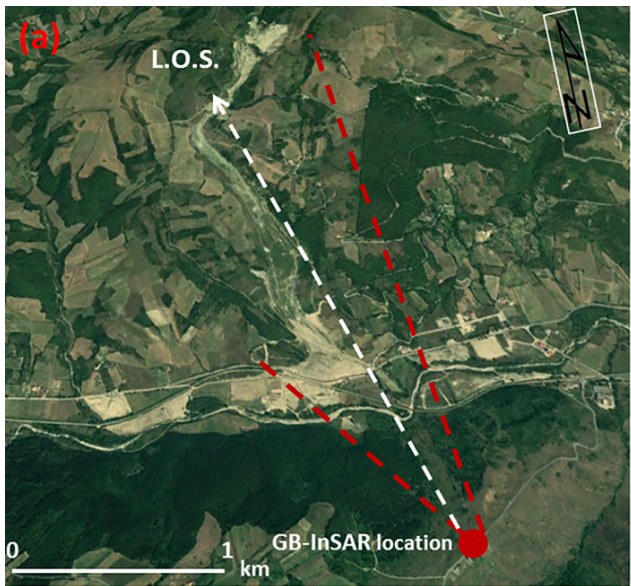

(b)

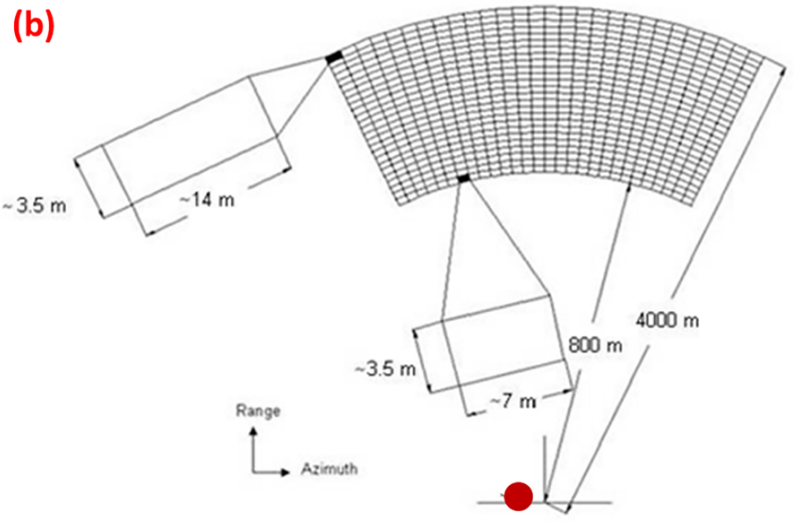

Figure 5. Location of the GB-InSAR system installation (a) and resolution grid size and parameters used during the monitoring campaign (b).

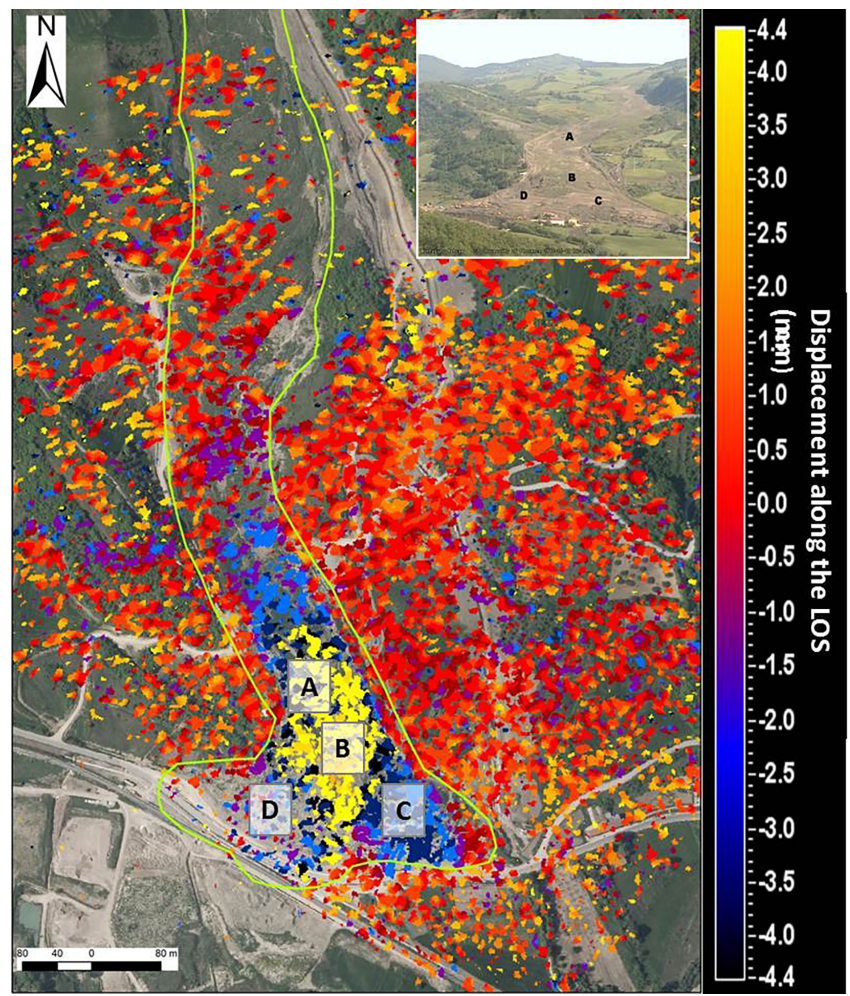

Figure 6. Interferogram covering a period spanning from 21:04 to 21:08 of 1 May 2010. Negative values indicate movement towards the instrument; top left corner: optical image of the Montaguto earthflow from the GB-InSAR installation point. Capital letters indicate the sectors selected for velocity estimation.

\section{Results and discussion}

\subsection{GB-InSAR data}

The toe of the landslide is the sector that experienced the highest detected velocity during the emergency phase
(Fig. 6). The average displacement rate reached approximately $1.0 \mathrm{~m} \mathrm{day}^{-1}$, although there were significant intra-day fluctuations. The maximum recorded velocity was measured at $2.9 \mathrm{~m} \mathrm{day}^{-1}$ on 1 June 2010 .

To understand the kinematics of the entire landslide toe, four sectors were identified during the emergency phase (A, B, C and D) (Fig. 6) to represent the main reference points for assessing landslide evolution. Aiming for an operational purpose, such sectors have not been identified based on geomorphological criteria but only on their displacement velocity, as visible on the interferograms (Fig. 6). To better follow the temporal evolution of each sector, a representative pixel has been selected within each of them; hence displacement time series relative to these pixels have been obtained.

During the months following the emergency phase, two more unstable areas were identified, labeled sectors $\mathrm{E}$ and $\mathrm{F}$ (Fig. 7). From the beginning, the data processing has been subjected to many variations induced by the landslide evolution.

In the initial monitoring days, the velocity of the landslide was so high that the interferograms needed to be calculated over a very short time interval (around $4 \mathrm{~min}$ ) (Fig. 6).

When the velocity started to decrease, the displacement cumulated in $4 \mathrm{~min}$ was lower than the sub-millimeter sensitivity of the GB-InSAR and therefore displacements were only detectable on $4 \mathrm{~h}$ interferograms (Fig. 9.1-2) and, later, on $24 \mathrm{~h}$ interferograms (Fig. 9.6). In March 2011, the E sector is very clearly detectable even in the $4 \mathrm{~h}$ temporal baseline (Fig. 9.8), and interferograms in Fig. 9.8-9 show the progress of the works implemented for the Rio Nocelle water channeling and the upper-medium sector works. Finally, starting from March 2011, with the aim of making the monitoring activities even more suitable for landslide evolution analysis, monthly cumulated maps were processed for the entire acquisition period (a monthly cumulated maps time laps is available in the Supplement). The elaborated cumulated displacement maps are represented with a color scale for visual- 


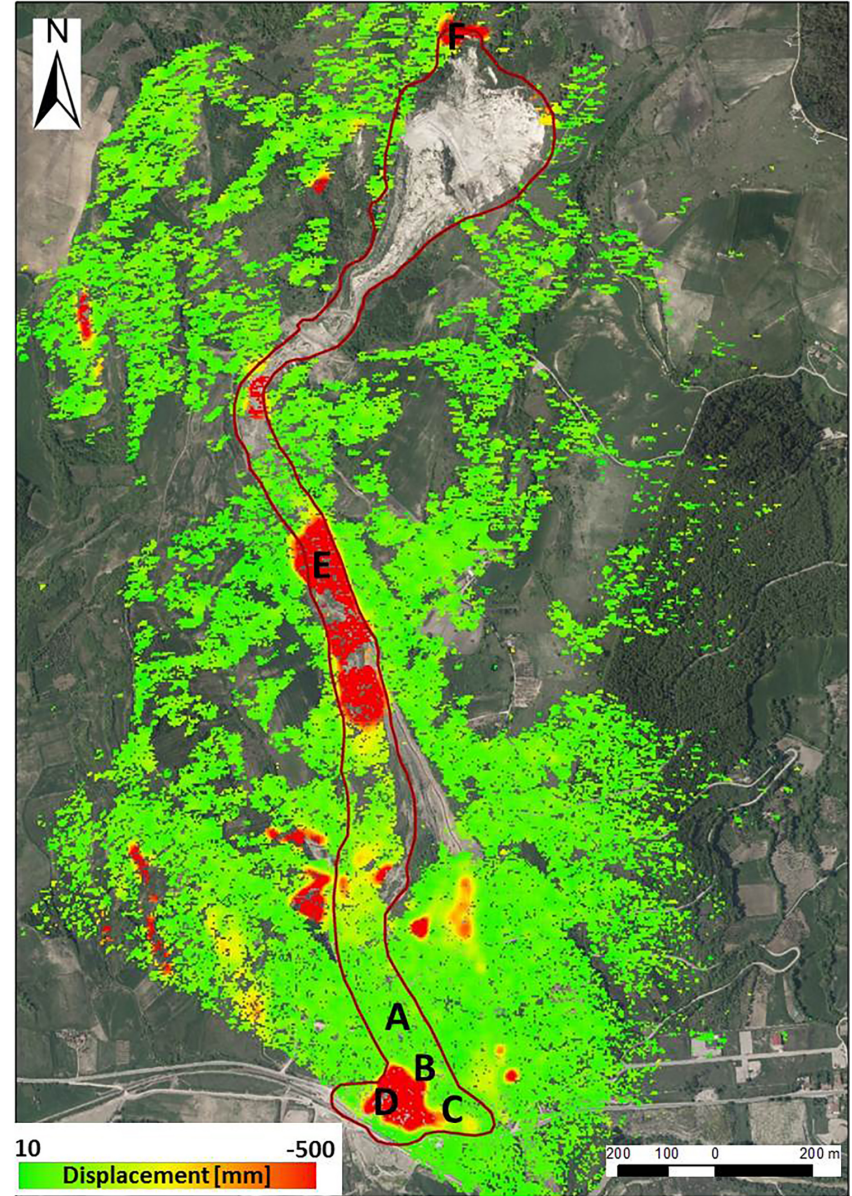

Figure 7. Monthly cumulated displacements (mm) map recorded between 1 and 31 March 2011. Negative values indicate movement towards the instrument.

izing (i) stable areas in light green, (ii) areas characterized by displacement towards the sensor LOS with colors from yellow to red and purple (maximum cumulated displacements) and (iii) areas characterized by displacements away from the sensor LOS with colors from dark green to deep blue.

Some monitored sectors have slowly continued to deform. For example, the D sector and a strip upstream in sector A continued a slow movement from December 2010, whereas the $\mathrm{E}$ and $\mathrm{F}$ sectors started their slow and intermittent movement in a later time. Movement in the E sector (located in the middle-upper part of the landslide) had movement detected in November 2010; in the F sector (the upper main scarp of the landslide) deformation was detected in December 2013.

From the data analysis and interpretation, it was possible to recognize and define the evolution of the observed phenomenon, in terms of a decrease and an increase of the deformation rate.

Because the stabilization projects were continuously checked and monitored by the GB-InSAR system and the draining and channeling works were efficiently carried out,

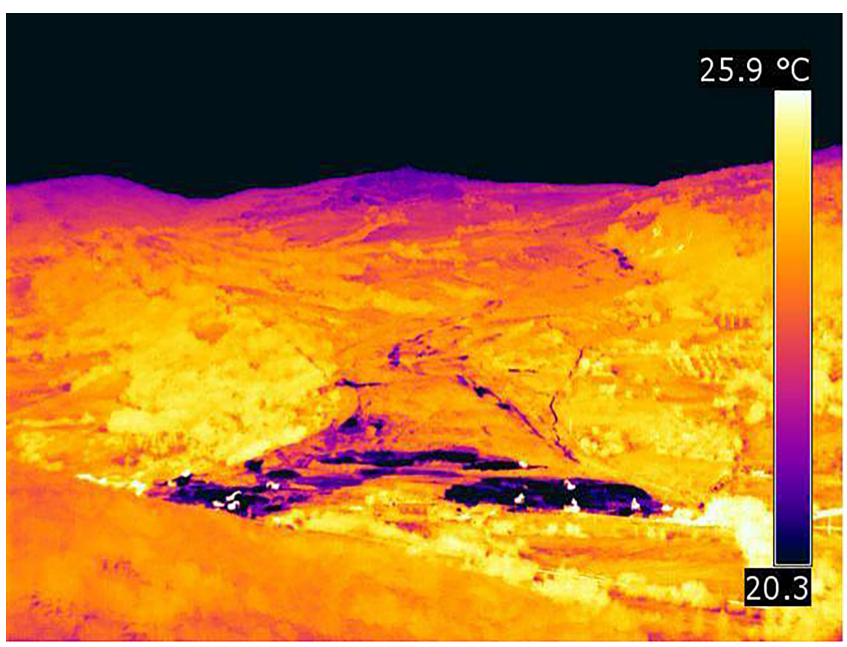

Figure 8. Thermal image of the Montaguto earthflow from the GBInSAR installation point (acquisition time: 11 May 2010, 11:00); dark pixels correspond to wet areas. For scale reference, the toe is $400 \mathrm{~m}$ large and the white dots on the wet areas are bulldozers reshaping the toe.

it was possible to determine that the deformation processes and movement speeds were gradually decreasing (Fig. 10).

\subsection{Landslide stabilization works}

After performing an analysis of the results of recent surveys and direct observation of the area, as well as the results from the monitoring, a design for stabilization works was established that can be updated and adapted, depending on the landslide response to the stabilization efforts. In September 2010, the main work phases were outlined. This represents the first application of the OM, referring to the $a b$ initio approach, previously mentioned.

The observations of the surface features produced by differential movement of the landslide and the analysis of the monitoring data enabled to understand the behavior of different parts of the landslide and to estimate a zonation of landslide elements; therefore, to better plan and conduct the required interventions, the earthflow has been divided into three zones. For each of them the most appropriate works were defined accordingly (Fig. 11).

- Upper sector (depletion zone): lake drainage, upstream surface drainage (diversion ditches), re-profiling of the main scarp, modification of the slope profile and restoration of stream channels to their natural conditions.

- Middle sector (main track): modification of the slope profile, surface drains coupled with deep trench drains, left-bank stream channelization and right-bank stream channelization. 

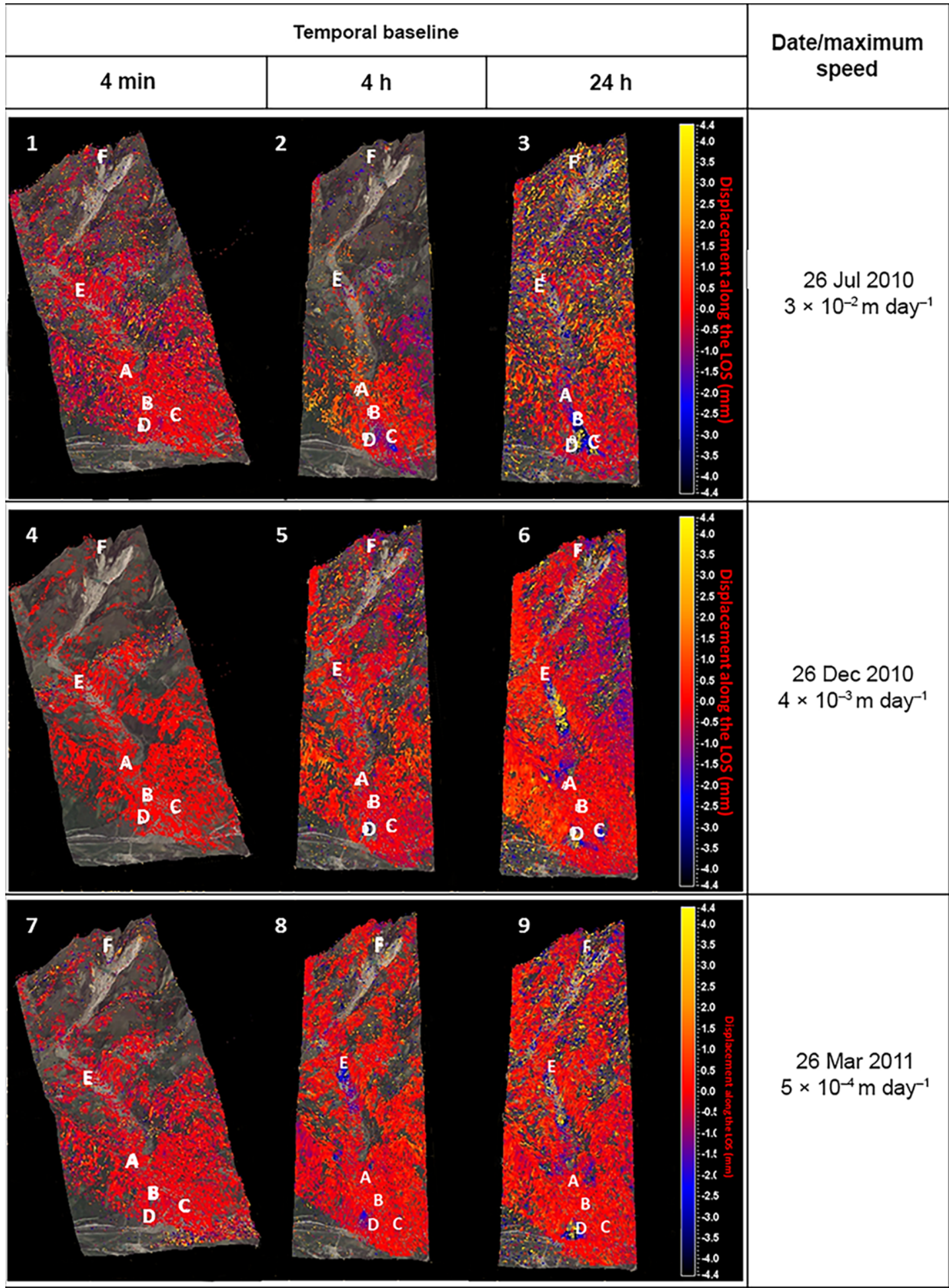

Figure 9. SAR interferograms showing typical displacement signals in unstable sectors with different temporal baselines during the first year. $(\mathbf{1}, \mathbf{2}, \mathbf{3})$ The temporal baseline of $4 \mathrm{~min}(\mathbf{1})$ does not allow for detection of the occurred displacement during July 2010 . The temporal baseline of $4 \mathrm{~h}(\mathbf{2})$ is able to show landslide toe displacement. $(4,5,6)$ The temporal baselines in $\mathrm{D}$ and $\mathrm{E}$ do not allow for detection of the occurred displacement during December 2010. (6) shows the unstable E sector. (7, 8, 9) During March 2011, SAR interferograms in (8) and (9) show the progress of the works implemented for the Rio Nocelle water channeling and the upper-medium sector works. 


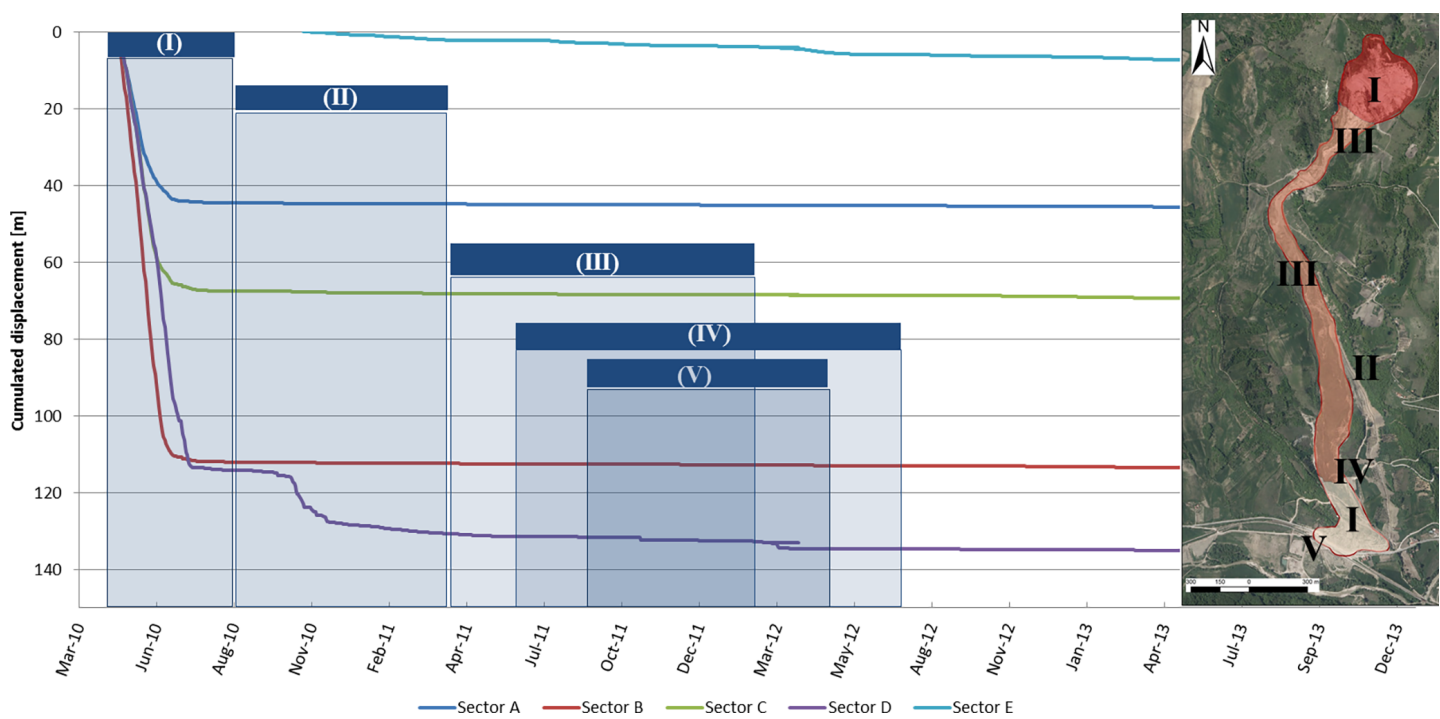

Figure 10. Displacement time series of representative points within the monitored sectors and verification of the efficiency of works with the time history of the velocity recorded at critical points: (I) drainage of the upstream and lower sector; (II) Rio Nocelle water channeling (Fig. 11, no. 7-10); (III) upper-medium sector works; (IV) medium-low sector works; and (V) toe sector works. See Fig. 11 for the stabilization works details and location.

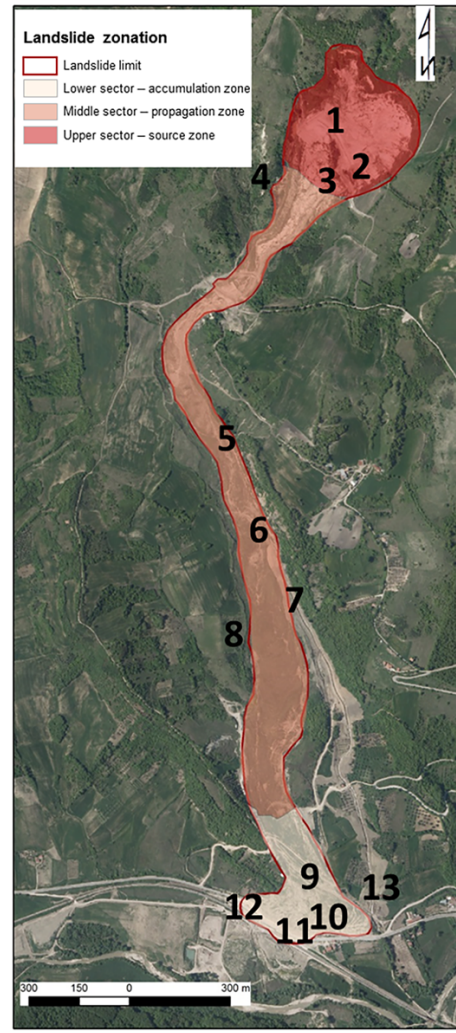

Upper sector (depletion zone)

1. Lake drainage

2. Upstream surface drainage (diversion ditches)

3. Re-profiling of the main scarp - profile modification

4. Stream channels restoration to natural conditions

Middle sector (main track)

5. Slope profile modification

6. Surface drains coupled with deep trench drains

7. Left-bank stream channelization

8. Right-bank stream channelization

\section{Lower sector (deposition zone)}

9. Landslide deviation on the left side

10. Surface drains coupled with deep trench drains

11. Gabion toe drain and buttressing

12. Re-profiling of landslide deposits on the right side

13. Left-bank stream channelization

Figure 11. Stabilization works plan and their distribution along the landslide. 

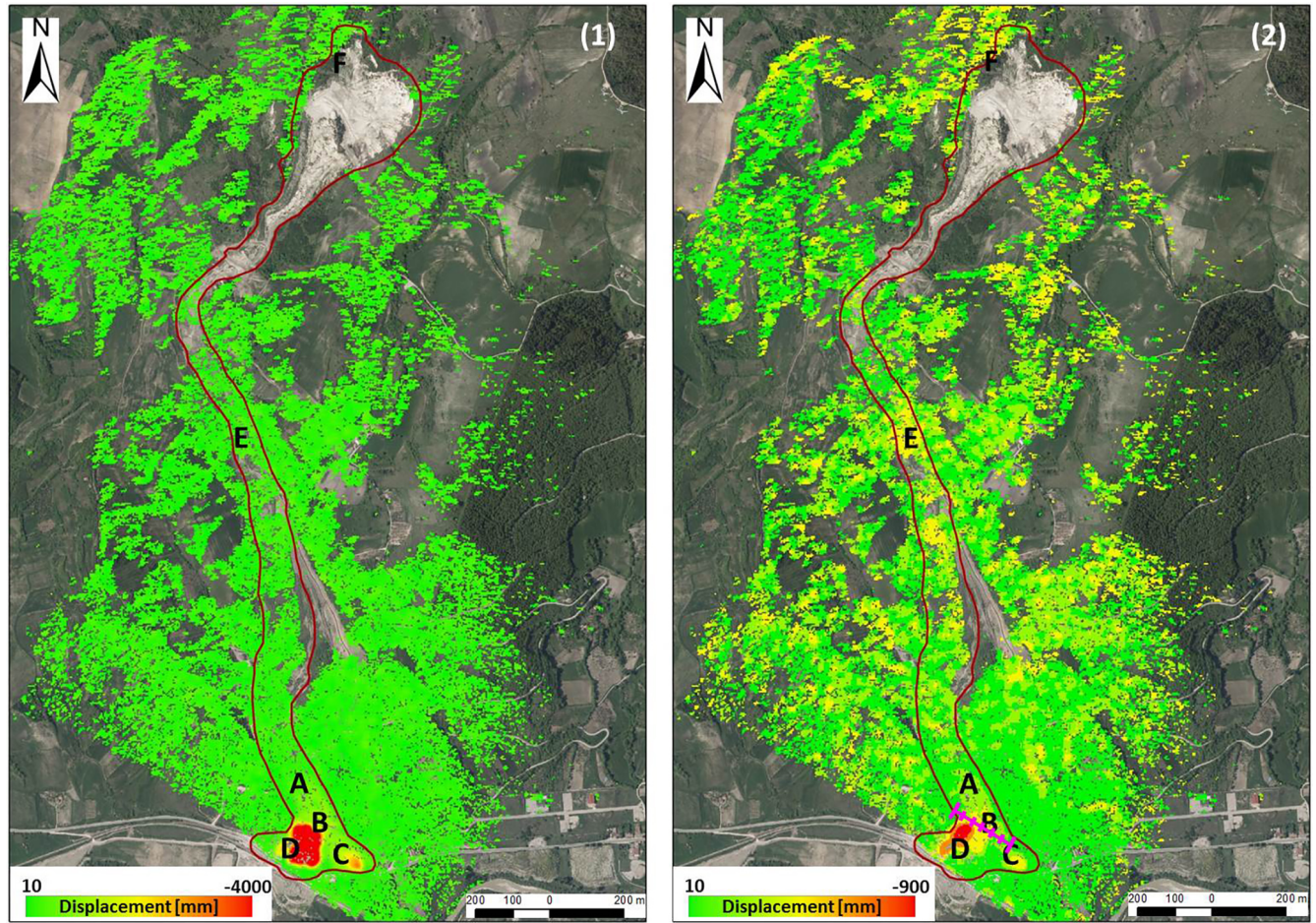

Figure 12. Monthly cumulated displacement maps: (1) in July 2010, the interferometric data show abundant stagnant water within the surface depressions, affecting sectors D and C; (2) during August 2010, the interferometric data show the efficiency of the realized cross trench (in pink - stabilization work no. 10 in Fig. 11).

- Lower sector (deposition zone): landslide deviation on the left side, surface drains coupled with deep trench drains, gabion toe drain and buttressing, re-profiling of landslide deposits on the right side and left-bank stream channelization.

As water was the main driving force of the landslide, contributing to a widespread increase in pore pressure, the primary objective of the undertaken actions was to remove it, both from the surface and from the deep layers. Thermal monitoring was therefore used to assess the wettest areas while displacement monitoring permitted to set a priority on the highest moving zones. The restoration of an effective surface circulation has thus been planned, coupled with drainage trenches that are able to collect deep groundwater.

The upper part of the landslide was characterized by the presence of a system of lakes, whose water was directed by drainage trenches and shallow channels into a well and then channeled into a watershed located outside the landslide (Fig. 11).

Shallow channels with hydraulic jumps were constructed in the middle part of the landslide. Deep drainage trenches that allowed deep groundwater to spring outward at the sites of hydraulic jumps were an integral part of the design.

The construction of shallow channels coupled with deeper groundwater drainage trenches was repeated at the lower part of the landslide. The water from the lower part and from lateral channel system is conveyed towards a natural watercourse that flows beyond the toe of the slide (Fig. 11).

The GB-InSAR monitoring data analysis was essential for the location and effectiveness assessment of the lower one, whose stabilizing effects were clearly visible to the radar apparatus (Fig. 12). In this manner, the abundant stagnant water within the surface depressions that had been created by the landslide was eliminated, thus reducing water infiltration and the rate of movement.

The stabilization works involving gabions and profiling of the landslide started at the toe (Fig. 13, blue box), where the interventions for water drainage were completed, with the goals of protecting the state road and the railway and restoring their use.

First, steel-reinforced gabions were installed to build retaining and permeable systems of considerable size (lower sector). Then, the landslide was reshaped in accordance with the constructed drainage works (middle sector). The location and timing of the interventions were selected based on the monitoring data results (Fig. 14).

Regarding the middle sector, a very interesting example of the coupled integration between GB-InSAR and work design and execution is the analysis of the landslide behavior in the mid-sector, i.e., the so-called "elbow" (E sector): here, the movement increased during November 2011-May 2012 despite the execution of the drainage works (Fig. 14). The 


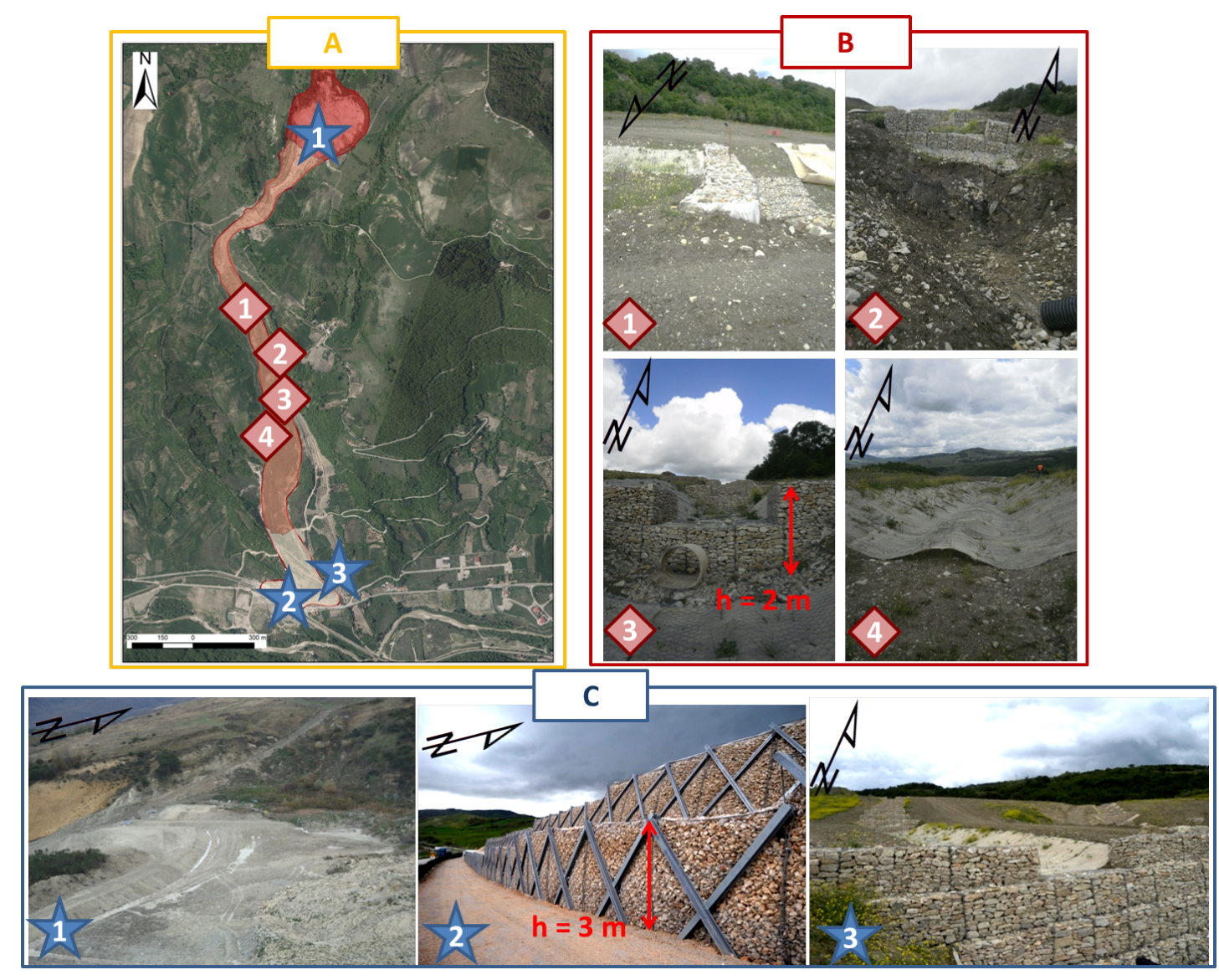

Figure 13. (a) Location of some remedial works along the landslide; (b) various forms of damage to the weirs $(1,2$ and 3$)$ and to the channel geotextile filter (4). The damages were caused by the slow and constant displacement located in the E sector. (c) Photos showing the primary important completed works: (1) drainage systems at the bottom of the main scarp, (2) gabion rock toe buttress and drain, (3) surface drains coupled with deep trench drains and (d) Rio Nocelle water channeling

activity and evolution of this sector was promptly highlighted by GB-InSAR data; the monthly displacement cumulated maps refer to the two highest deformation rate periods (March-April 2012), when the velocity reached approximately $1 \mathrm{~cm} \mathrm{day}^{-1}$. To verify this information, some field surveys were performed that showed the damage to three weirs and the geotextile filter (Fig. 13b). Based on these observations, a design variation involving additional drainage elements in the main channels (Fig. 11, no. 10) was incorporated into the design (Fig. 12). This variation constitutes a valid example of the "best way out" approach, as suggested by Peck (1969).

To highlight the project's efficiency in relation to the slowing rate of displacement, a velocity graph was constructed to compare the beginning and end of the different stabilization works affecting the most unstable area, identified as the $\mathrm{E}$ sector (Fig. 15). In May 2012, most of the stabilization works were completed.

Because of the high acquisition rate and accuracy of GBInSAR data, the efficiency of the undertaken activities was continuously verified through the OM by observing the time series of the velocity recorded at critical points (Fig. 16i).

The prosecution of monitoring verified the long-term effectiveness of the stabilization works, which prevented reactivations even after rainy periods (Fig. 16iii) (with a small acceleration of sector D during early autumn 2010 being the only exception).

The GB-InSAR was also used as an early warning tool. During the very initial phase of the emergency, when the earthflow displacements were high, a warning velocity threshold was set at a level of $2 \mathrm{~m} \mathrm{day}^{-1}$. The threshold was exceeded on the 10, 14, 24, 25 and 31 days of May 2010; during these days, people involved in interventions were recommended to take particular care during the execution of the works located at the landslide toe area (sectors B, C and D) (Fig. 16ii).

The Montaguto landslide thus represents a very interesting example of hydraulic and structural engineering techniques in stabilization work focused on minimizing the envi- 

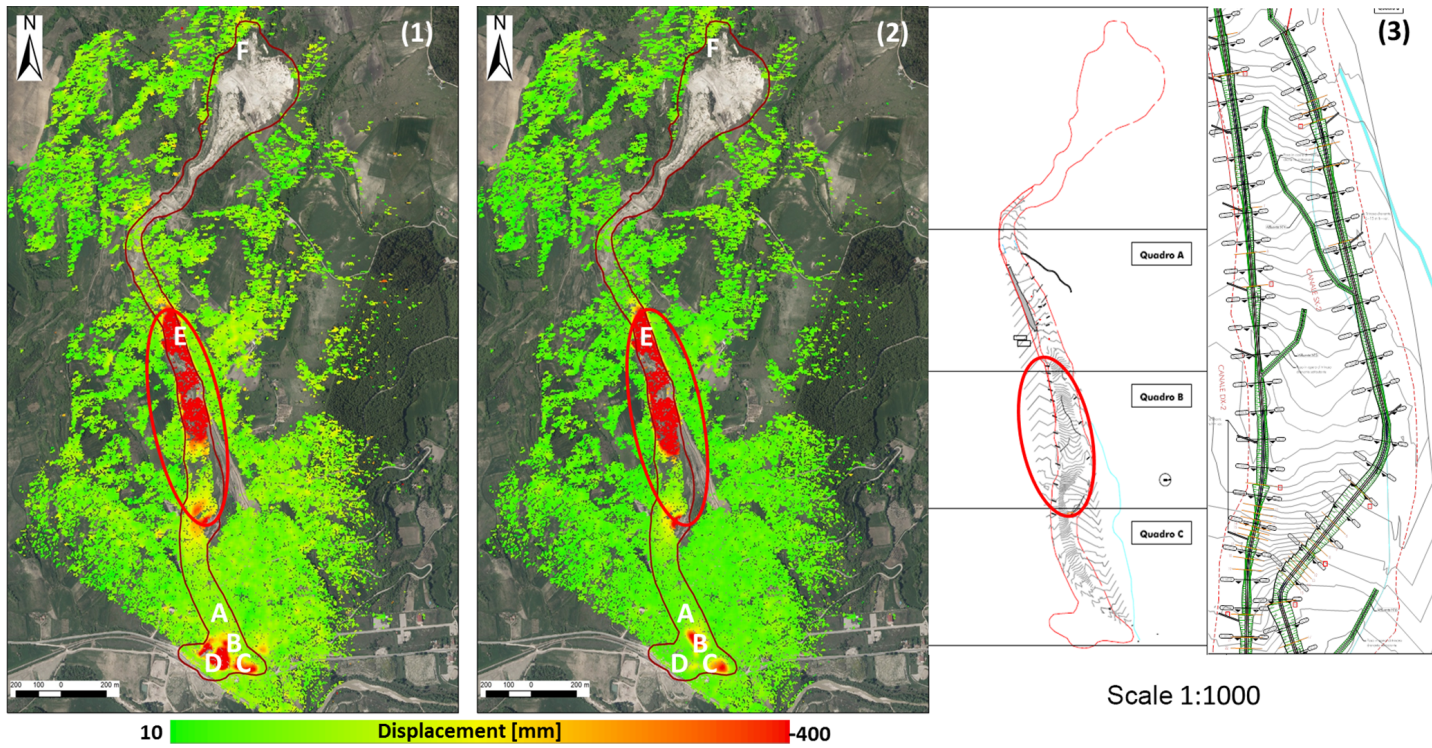

Figure 14. Monthly cumulated maps for March (1) and April (2) 2012 showing the interferometric evidence of the deformation phenomena affecting the $\mathrm{E}$ sector and the subsequent design variant (3).

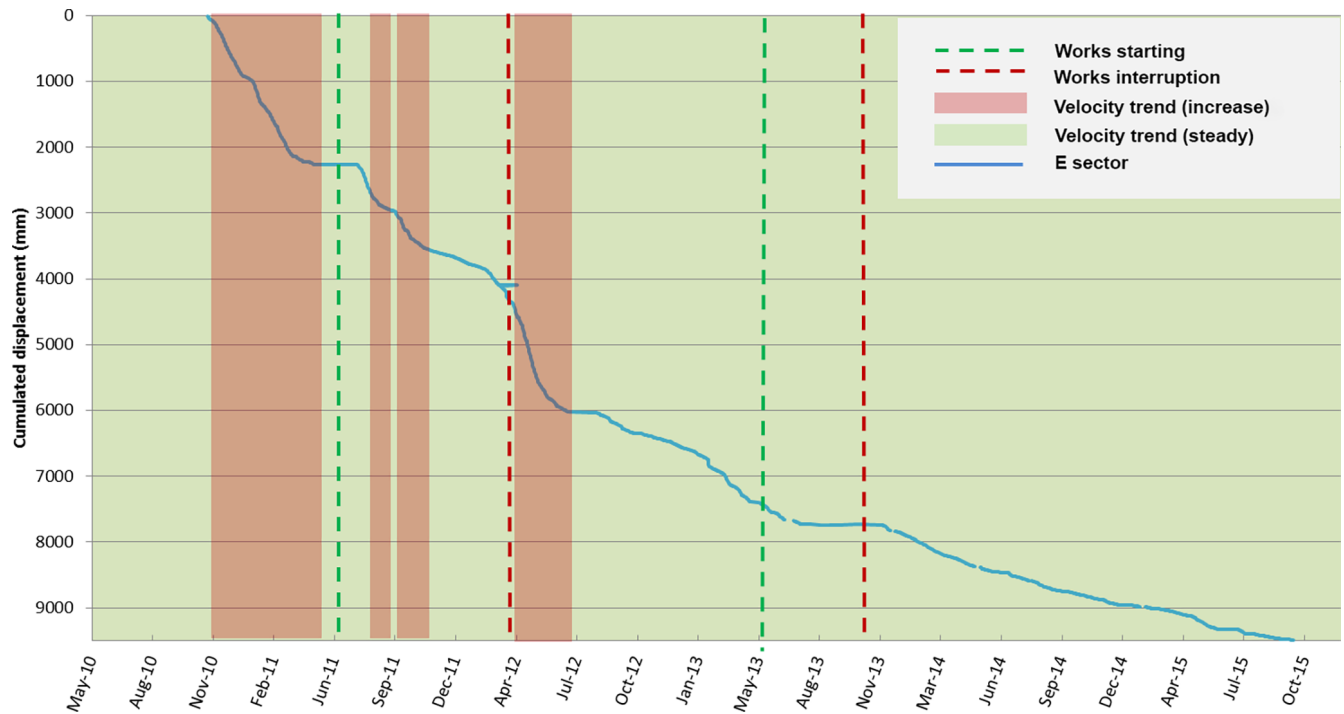

Figure 15. Cumulated displacement recorded at the E sector and work phases over time.

ronmental impact, the execution and effectiveness of which have been driven and evaluated by accurate monitoring data.

\section{Conclusions}

The application of the GB-InSAR technique for monitoring the Montaguto earthflow was demonstrated to be capable of continuously acquiring accurate displacement measurements over large areas. The GB-InSAR technique has a high image acquisition rate and the capacity to provide displacement maps with sub-millimeter accuracy, making it specif- ically suited for assessing slope instability problems, especially during emergency conditions.

The GB-InSAR approach proved to be very useful for the application of the OM during the emergency phase. It allowed a quick delineation of the slide and, through the detection of the more unstable areas, supported the stabilization and excavation planning and design. The day-to-day comparison between the works in progress and the GB-InSAR data allowed for the detection and evaluation of the landslides response and evolution. Moreover, these coupled activities allows planning of the work phases that will greatly increase the safety of workers and community alike. The areal map- 

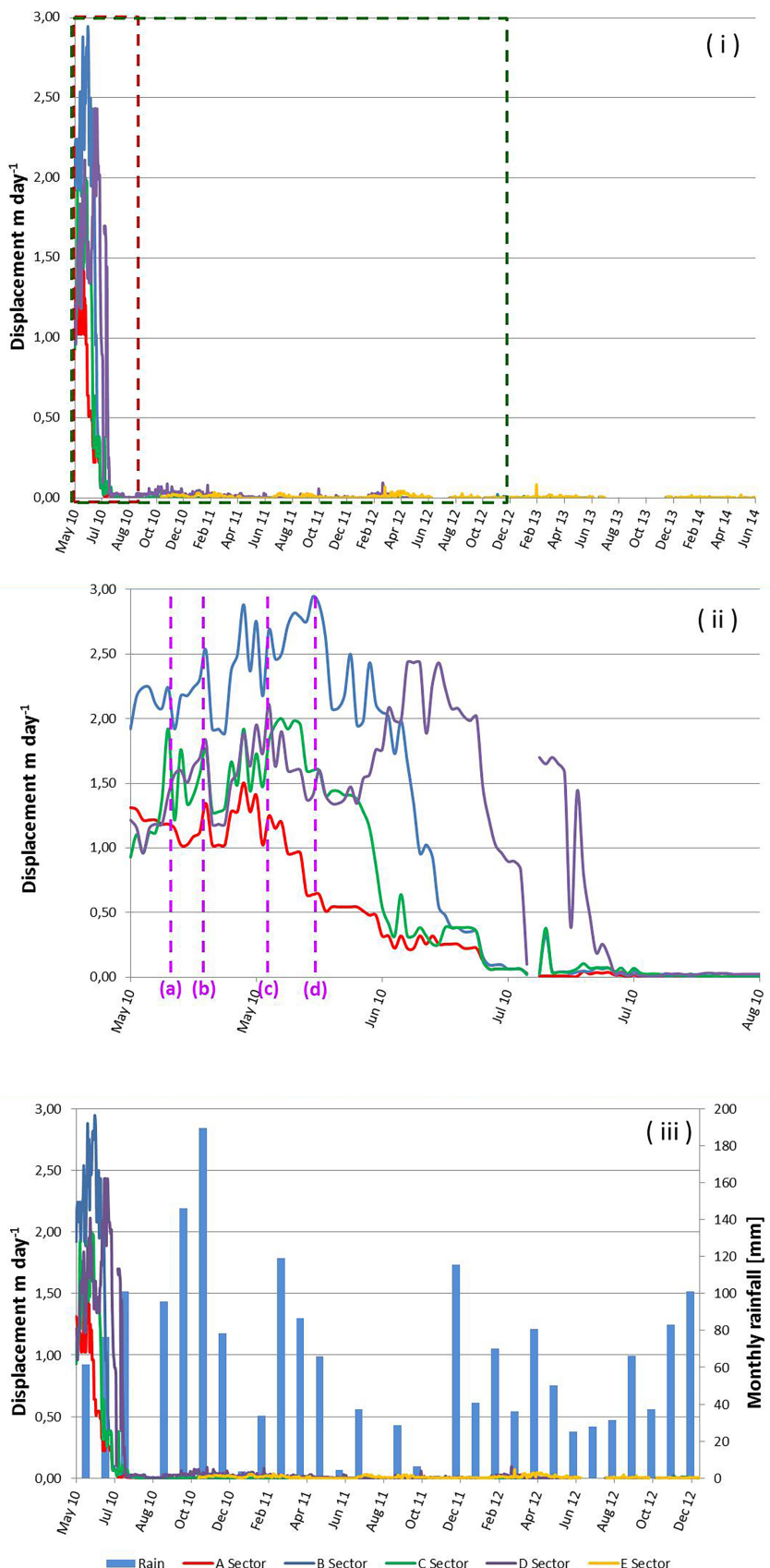

Figure 16. (i) Recorded velocity at the different sectors. (ii) The $2 \mathrm{mday}^{-1}$ threshold was exceeded on the following days: (a) 10 May 2010, sector B reached $2.2 \mathrm{~m} \mathrm{day}^{-1}$; (b) 14 May 2010 the sector B velocity was recorded up to $2.5 \mathrm{~m}$ day $^{-1}$, sectors A, C and $\mathrm{D}$ were affected by a lower but comparable trend; (c) between 24 and 25 May, sectors B, C and D reached the velocity of 2.3, 2 and $2.1 \mathrm{~m} \mathrm{day}^{-1}$, respectively; (d) maximum velocity recorded was $2.9 \mathrm{~m} \mathrm{day}^{-1}$ on 31 May 2010. (iii) Recorded velocity at the different sectors compared with the monthly cumulated rainfall. ping of displacements over the entire slope is very useful in identifying areas of complex deformation patterns with different rates of movement.

The results during this study period showed a general decrease in the rates of displacement. Nevertheless, some unstable sectors were detected, characterized by deformations having both characteristics of temporal persistence (the landslide is inactive but not stable) and heterogeneity (some areas reached high displacement rates more often than others sectors and/or at different times).

Use of real-time monitoring with new technologies allowed us to accomplish documentation of 4 years of daily activity.

Through the daily monitoring activities, it was also possible to enrich the study by using the OM approach. This allowed us to establish the efficiency of the works and to direct possible project variations.

Data availability. Since the data used in this paper were the results of different agreements with the National and Regional (Campania Region) Civil Protection Departments, they are subjected to availability restrictions and they are not public.

\section{The Supplement related to this article is available online at https://doi.org/10.5194/nhess-17-845-2017- supplement.}

Competing interests. The authors declare that they have no conflict of interest.

Acknowledgements. This work has been funded by the National Civil Protection Department. Special thanks goes to Paolo Barsotti (Ingeo s.r.1.) and to Davide Leva (ELLEGI). The authors thank the editor Andreas Günther and five anonymous reviewers for their comments and suggestions.

Edited by: A. Günther

Reviewed by: five anonymous referees

\section{References}

Allasia, P., Manconi, A., Giordan, D., Baldo, M., and Lollino, G.: ADVICE: A New Approach for Near-Real-Time Monitoring of Surface Displacements in Landslide Hazard Scenarios, Sensors, 13, 8285-8302, 2013.

Atzeni, C., Basso, M., Canuti, P., Casagli, N., Leva, D., Luzi, G., Moretti, S., Pieraccini, M., Sieber, A. J., and Tarchi, D.: Ground-based SAR interferometry for landslide monitoring and control ISSMGE Field Workshop on Landslides and Natural/Cultural Heritage, Trabzon (Turkey), 23-24 August 2001, 195-209, (CNR GNDCI Pub. No.2375), 2001. 
Badoux, A., Graf, C., Rhyner, J., Kuntner, R., and Mcardell, B. W.: A debris-flow alarm system for the Alpine Illgraben catchment: design and performance, Nat. Hazards, 49, 517-539, 2009.

Balducci, M., Regni, R., Buttiglia, S., Piccioni, R., Venanti, L. D., Casagli, N., and Gigli, G.: Design and built of a ground reinforced embankment for the protection of a provincial road (Assisi, Italy) against rockslide Proc. XXIV Conv. Naz. Geotecnica, AGI, Napoli, 22-24 June 2011.

Bardi, F., Raspini, F., Frodella, W., Lombardi, L., Nocentini, M., Gigli, G., Morelli, S., Corsini, A., and Casagli, N.: Monitoring the Rapid-Moving Reactivation of Earth Flows by Means of GB-InSAR: The April 2013 Capriglio Landslide (Northern Appennines, Italy), Remote Sens., 9, 165, https://doi.org/10.3390/rs9020165, 2017.

Barla, G. B., Antolini, F., Barla, M., Mensi, E., and Piovano, G.: Monitoring of the Beauregard landslide (Aosta Valley, Italy) using advanced and conventional techniques, Eng. Geol., 116, 218 $235,2010$.

Boccardo, P.: New perspectives in emergency mapping, Eur. J. Remote Sens., 46, 571-582, https://doi.org/10.5721/EuJRS20134633, 2013.

Bozzano, F., Cipriani, I., Mazzanti, P., and Prestininzi, A.: Displacement patterns of a landslide affected by human activities: insights from ground-based InSAR monitoring, Nat. Hazards, 59, 13771396, https://doi.org/10.007/s11069-011-9840, 2011.

Calò, F., Calcaterra, D., Iodice, A., Parise, M., and Ramondini, M.: Assessing the activity of a large landslide in southern Italy by ground-monitoring and SAR interferometric techniques, Int. J. Remote Sens., 33, 3512-3530, 2012.

Canuti, P., Casagli, N., Farina, P., Leva, D., Tarchi, D., and Nico, G.: Some examples of slope movements monitored by ground-based SAR interferometry, in: Proceedings IC-FSM2003 International Conference on Fast Slope Movements: Prediction and Prevention for Risk Mitigation, edited by: Picarelli, L., 71-77, Sorrento (Italy), 11-13 May 2003.

Carlà, T., Intrieri, E., Di Traglia, F., Nolesini, T., Gigli, G., and Casagli, N.: Guidelines on the use of inverse velocity method as a tool for setting alarm thresholds and forecasting landslides and structure collapses, Landslides, 14, 517, https://doi.org/10.1007/s10346-016-0731-5, 2016.

Casagli, N., Del Ventisette, C., Mannucci, G., La Rocca, L., Ballini, A., Antonello, G., Fortuny-Guasch, J., Tarchi, D., and Leva, D.: Ground-based interferometry for monitoring an active rockslide in the Italian Alps, Geophys. Res. Abstr., vol. 10, 08818-08818, ISSN:1029-7006, 2008.

Casagli, N., Catani, F., Del Ventisette, C., and Luzi, G.: Monitoring, prediction, and early warning using ground-based radar interferometry, Landslides, 7, 291-301, https://doi.org/10.1007/s10346010-0215-y, 2010.

Coe, J. A., Ellis, W. L., Godt, J. W., Savage, W. Z., Savage, J. E., Michael, J. A., and Debray, S.: Seasonal movement of the Slumgullion landslide determined from Global Positioning System surveys and field instrumentation, July 1998-March 2002, Eng. Geol., 68, 67-101, 2003.

Crostella, A. and Vezzani, L.: La geologia dell'Appennino Foggiano, Boll. Soc. Geol. Ital., 83, 121-141, 1964 (in Italian).

Curlander, J. C. and Mcdonough, R. N.: Synthetic Aperture Radar: Systems and Signal Processing, ISBN: 978-0-471-85770-9, 672 pp., 1992.
D’Argenio, B., Pescatore, T., and Scandone, P.: Structural pattern of the Campania-lucania Apenines, in: Structural Model of Italy. Quaderni de "La Ricerca Scientifica", 90, edited by: Ogniben, L., Parotto, M., and Praturlon, A., Consiglio Nazionale delle Ricerche, Roma, 313-327, 1975 (in Italian).

FSnews: available at: http://www. fsnews.it/cms/v/index.jsp?vgnextoid= a94b3a05be177210VgnVCM1000004016f90aRCRD, last access: 15 April 2016.

Gigli, G., Fanti, R., Canuti, P., and Casagli, N.: Integration of advanced monitoring and numerical modeling techniques for the complete risk scenario analysis of rockslides: The case of Mt. Beni (Florence, Italy), Eng. Geol., 120, 48-59, 2011.

Gigli, G., Intrieri, E., Lombardi, L., Nocentini, M., Frodella, W., Balducci, M., Venant, L. D., and Casagli, N.: Event scenario analysis for the design of rockslide countermeasures, J. Mountain Sci., 6, 1521-1530, 2014.

Giordan, D., Allasia, P., Manconi, A., Baldo, M., Santangelo, M., Cardinali, M., Corazza, A., Albanese, V., Lollino, G., and Guzzetti, F.: Morphological and kinematic evolution of a large earthflow: the Montaguto landslide, southern Italy, Geomorphology, 187, 61-79, https://doi.org/10.1016/j.geomorph.2012.12.035, 2013.

Guadagno, F. M., Forte, R., Revellino, P., Fiorillo, F., and Focareta, M.: Some aspects of the initiation of debris avalanches in the Campania Region: the role of morphological slope discontinuities and the development of failure, Geomorphology, 66, 237254, 2005.

Guerriero, L., Revellino, P., Coe, J. A., Focareta, M., Grelle, G., Albanese, V., Corazza, A., and Guadagno, F. M.: Multi-temporal maps of the Montaguto Earth Flow in Southern Italy from 1954 to 2010, J. Maps, 9, 135-145, 2013.

Hungr, O., Leroueil, S., and Picarelli, L.: The Varnes classification of landslide types, an update, Landslides, 11, 167-194, https://doi.org/10.1007/s10346-013-0436-y, 2013.

Intrieri, E., Gigli, G., Mugnai, F., Fanti, R., and Casagli, N.: Design and implementation of a landslide Early Warning System, Eng. Geol., 147-148, 124-136, 2012.

Intrieri, E., Gigli, G., Nocentini, M., Lombardi, L., Mugnai, F., and Casagli, N.: Sinkhole monitoring early warning an experimental and successful GB-InSAR application, Geomorphology, 241, 304-314, 2015.

Lollino, P., Giordan, D., and Allasia, P.: The Montaguto earthflow: A back-analysis of the process of landslide propagation, Eng Geol., 170, 66-79, 2014.

Lombardi, L., Nocentini, M., Frodella, W., Nolesini, T., Bardi, F., Intrieri, E., Carlà, T., Solari, L., Dotta, G., Ferrigno, F., and Casagli, N.: The Calatabiano landslide (Southern Italy): preliminary GB-InSAR monitoring data and remote 3D mapping, Landslides, 76, 1-18, https://doi.org/10.1007/s10346-016-07676, 2016.

Luzi, G.: Ground Based SAR Interferometry a Novel Tool for Geoscience, in: Imperatore, edited by: Riccio, D., Geoscience and Remote Sensing New Achievements, INTECH Open Access Publisher, 2010.

Luzi, G., Pieraccini, M., Mecatti, D., Noferini, L., Guidi, G., Moia, F., and Atzeni, C.: Ground-based radar interferometry for landslides monitoring: atmospheric and instrumental decorrelation 
sources on experimental data, IEEE T. Geosci. Remote Sens., 42, 2454-2466, 2004.

Matano, F.: Le Molasse di Anzano nell'evoluzione tettonosedimentaria messinianadel margine occidentale della microzolla apula nel settore Irpino-Dauno dell'orogene sud-appenninico, Mem. Soc. Geol. Ital., 57, 209-220, 2002 (in Italian).

Monserrat, O., Crosetto, M., and Luzi, G.: A review of groundbased SAR interferometry for deformation measurement, ISPRS J. Photogramm. Remote Sens., 93, 40-48, 2014.

Parise, M., Coe, J. A., Savage, W. Z., and Varnes, D. J.: The Slumgullion landslide (southwestern Colorado, USA): investigation and monitoring, in: Proc. Int. W. "Occurrence and mechanisms of flow-like landslides in natural slopes and earthfills", edited by: Picarelli, L., Patron, Bologna, 253-263, 2003.

Peck, R. B.: Advantages and Limitations of the Observational Method in Applied Soil Mechanics, Géotechnique, 19, 171-187, 1969.

Pescatore, T., Russo, B., Senatore, M. R., Ciampo, G., Esposito, P., Pinto, F., and Staiti, D.: La successione messiniana della valle del Torrente Cervaro (Appennino Dauno, Italia Meridionale), Boll. Soc. Geol. Ital., 115, 369-378, 1996 (in Italian).

Revellino, P., Grelle, G., Donnarumma, A., and Guadagno, F. M.: Structurally controlled earth flows of the Benevento province (Southern Italy), B. Eng. Geol. Environ., 69, 487-500, 2010.
Tarchi, D., Ohlmer, E., and Sieber, A. J.: Monitoring of structural changes by radar interferometry, Res. Nondestruct. Eval., 9, 213225, 1997.

Tarchi, D., Casagli, N., Fanti, R., Leva, D., Luzi, G., Pasuto, A., Pieraccini, M., and Silvano, S.: Landside Monitoring by Using Ground-Based SAR Interferometry: an example of application to the Tessina landslide in Italy, Eng. Geol. 68, 15-30, 2003a.

Tarchi, D., Casagli, N., Moretti, S., Leva, D., and Sieber, A. J.: Monitoring landslide displacements by using ground-based radar interferometry: Application to the Ruinon landslide in the Italian Alps, J. Geophys. Res., 108, 10.1-10.14, 2003b.

Terzaghi, K., Peck, R. B., and Mesri, G.: Soil mechanics in engineering practice. John Wiley \& Sons, 1996.

Ventura, G., Vilardo, G., Terranova, C., and Bellucci Sessa, E.: Tracking and evolution of complex active landslides by multi-temporal airborne LiDAR data: The Montaguto landslide (Southern Italy), Remote Sens. Environ., 115, 32373247,https://doi.org/10.1016/j.rse.2011.07.007, 2011.

Zebker, H. A. and Goldstein, R. M.: Topographic mapping from interferometric synthetic aperture radar observations, J. Geophys. Res., 91, 4993-4999, 1986. 